DOC.

101.60/2:

1752

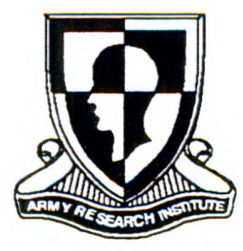

U.S. Army Research Institute

for the Behavioral and Social Sciences

Research Report 1752

\title{
Operational Assessment of Force XXI Training Products: Lessons for Successful Fielding
}

David M. Pratt, Christopher R. Graves, Charlotte H. Campbell, and Richard L. Detrani

Human Resources Research Organization

Bruce C. Leibrecht

TRW S\&ITG

Johnny D. Allen

Raytheon Systems Company

Samuel N. Jenkins

Litton PRC

Kathleen A. Quinkert

U.S. Army Research Institute

The Library of the

January 2000

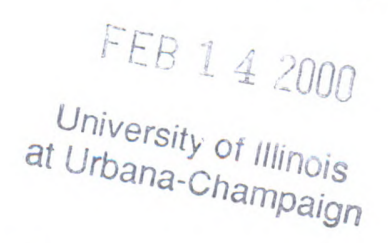

Approved for public release; distribution is unlimited. 